\title{
Evolution and function of the Chinese carved horse hitching stone post
}

\author{
Ke Bai \\ Shaanxi Institute for the Preservation of Cultural Heritage, Key Scientific Research Base of Stone and Brick \\ Conservation. NO.35, Keji 1 Road, Gaoxin District, Xi’an, Shaanxi, China. Email: Bk2042@qq.com
}

\begin{abstract}
:
This article focuses on a typical artefact in Mainland China: carved stone horse hitching posts and their distribution, history, types, and cultural meaning. It tries to interpret their evolution and the relationship between their functional and social change. This type of post was made exclusively for tying horses, from the Han Dynasty to the Yuan Dynasty (approximately 1st-13th century CE). Initially, posts were a practical tool used for simply tying horses, with no added symbolism. Later, the stone posts were carved with many decorative patterns. In the 1980's, tens of thousands of stone posts were rediscovered next to gates of rural residential houses and seldom in cities. Both archaeologists and artists try to organize this sequence and interpret the symbolism. Patterns used on the posts, originating from fairy tales, religion and life, have different meanings. Nowadays because of the beautiful patterns and implied meaning, the posts were transported to cities and collected by museums, universities, parks and artefact shops. A collection of stone posts was put together and merged into the roadside landscape. The posts are treated as an antiquity and as a symbol of culture, art and taste. The function and symbolism of Chinese carved stone hitching post changed with the development of agriculture and transportation. Some of its original functions vanished, and the value changed from a practical implement to a standard of wealth, good taste and culture.
\end{abstract}

Keywords: horse hitching post; wards off equine plague; Bi-ma-we; evolution; functions changing

\section{Introduction}

Horse hitching stone posts were made specifically for tying animals, especially horses, and were carved with different patterns and planted in front of farmers' houses in rural areas (Figure 1a), dating between 1800 and 1900.

Usually the stone posts had a height between $180-260 \mathrm{~cm}$. They consisted of four parts: a head, neck, body and foot (Figure 1b). The head, the most delicate part, was carved in the shape of animals, figures and symbols of fortune. The neck was formed in bas-relief, decorated with flowers and leaves or triangles. The body is cuboid or octagonal, and it was sometimes decorated in bas-relief or with characters. The foot usually is rough, and buried underground. Most of the head is openwork carving so that animals could be tied through the holes. Sometimes, an extra hole was drilled in the middle of the body.

Published by the School of History, Classics and Archaeology, University of Edinburgh ISSN: 2055-0472. URL: http://journals.ed.ac.uk/lithicstudies/ 


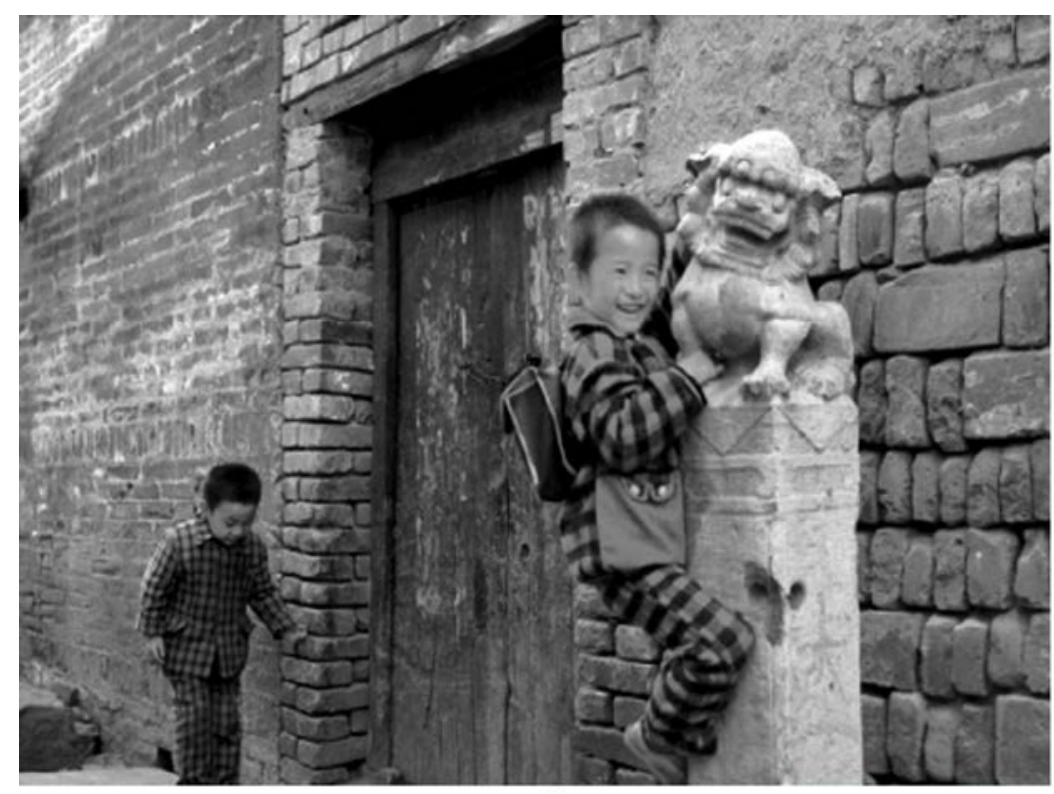

1a

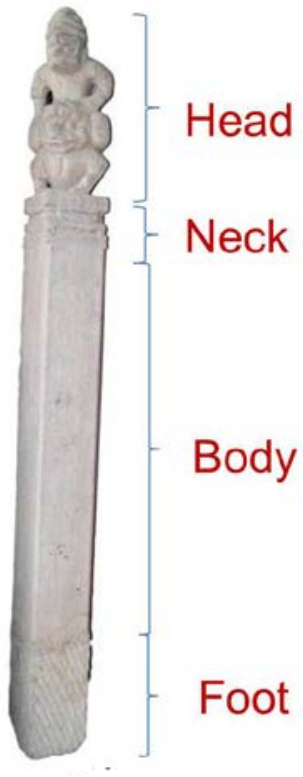

$1 \mathrm{~b}$

Figure 1. a) Horse hitching stone posts found originally before 1992. Photographed by Wugong Hu; b) Structure of horse hitching stone posts.

\section{Distribution}

Archaeologists (Wang \& Dang 1985) rediscovered the carved stone posts in the countryside of Shaanxi province. Until the 2010's, approximately 20,000-40,000 pieces were found in China, more than $50 \%$ of these distributed in the Shaanxi province. This Shaanxi province collection includes all the types found in China, so later investigations mainly focus on the posts in the Shaanxi province.

Early studies (Zhu 2008) indicate that horse hitching stone posts were mainly found in the Shaanxi, Gansu, Shanxi, Hebei and Henan provinces. However, more stone posts were found in other provinces, including the Liaoning and Jilin provinces in the northeast. Besides this, in the south of China, in the Anhui, Jiangsu, Guangxi provinces, horse hitching stone posts were found as well (Figure 2). All reports indicate that stone posts were found in front of rural residential houses (Figure 1a), and none were found in towns and cities. In recent years, horse hitching posts became more and more popular as a cultural phenomenon; public museums and private collectors traded dozens of pieces, making studies of these posts more complicated. Nowadays, few are left in rural areas.

\section{History}

\subsection{Inscriptions}

Many of the stone posts were carved with inscriptions. Some inscriptions clearly show the post's manufacturing year, so the inscriptions aid in studying when the posts were made. Yan (1991), Zhang (1992), Lin (2004) and Wu (2002) all documented inscriptions dating to the Qing Dynasty, so they concluded that the stone posts became popular around the Qing Qianlong period. Examples of such inscriptions read the April 4th, 19th year of Emperor Qianlong (1750), 20th year of Emperor Qianlong (1751), 29th year of Emperor Daoguang (1849), 9th year of Emperor Xianfeng (1859) and autumn of Bingzi (1756, 1816 or 1876). It is impossible to ascertain the origin of the stone posts though by inscriptions alone. 


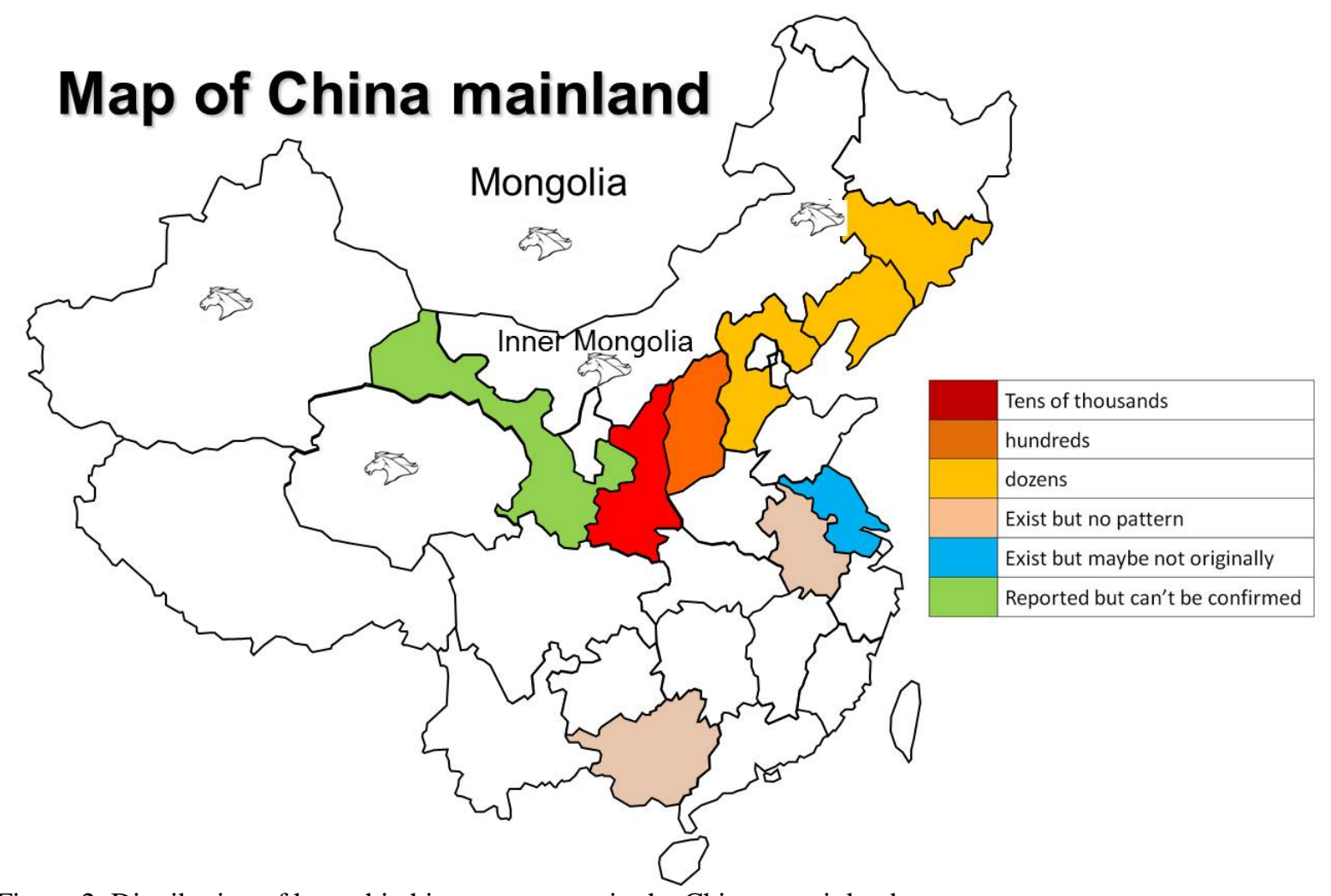

Figure 2. Distribution of horse hitching stone posts in the Chinese mainland.

\subsection{Archives}

No horse hitching stone posts were found dating to before the 18th century; however, early studies did not reach a reassuring conclusion about the origin of the stone posts. Ye \& Meng (2017) also found paintings from the Tang Dynasty with images of horse hitching posts (Figure 3a, b). Zhou et al. (2011) believes that the stone posts appeared in the Han or Tang Dynasty, based on art style of carved posts.

Actually, images of posts were depicted on excavated tomb stones, bricks and famous paintings, dating to much earlier periods: the earliest images of horse hitching post were found on tomb stone reliefs in the Eastern Han Dynasty (25-220 CE) with images depicting horse breeding. In the same period, trees (Figure 4a, b), wooden posts (Figure 4c-e) and carved wooden posts (Figure 4f) were used as well to tie horses. Sun (1991) found that the wooden posts (Figure 4d, e), which were specially made for tying horses, were called Ma'ang 马枊 during the Han Dynasty.

A hundred years later, several famous paintings also have images of horse hitching posts. These include the Map of Zhao Yebai, Gan Han, 706-783 CE (Figure 3a) and the Map of Hundred Horses, Yan We, (Figure 3b), a painting on an excavated tomb brick (Northern Song 960-1127 CE, Figure 5a) and the Map of Nine Horses, Renfa Ren, 1254-1327 CE, Yuan Dynasty (Figure 5b). In these paintings, horses were tied to posts, but the posts are probably wooden.

Thus, we can conclude that in early periods, horse hitching posts were mainly wooden, with less carving or decoration on the top. Wood is much more easily broken and destroyed, so it has to be replaced more frequently. Thus, probably due to this fact, wooden hitching posts are not preserved, and early examples cannot be found. 

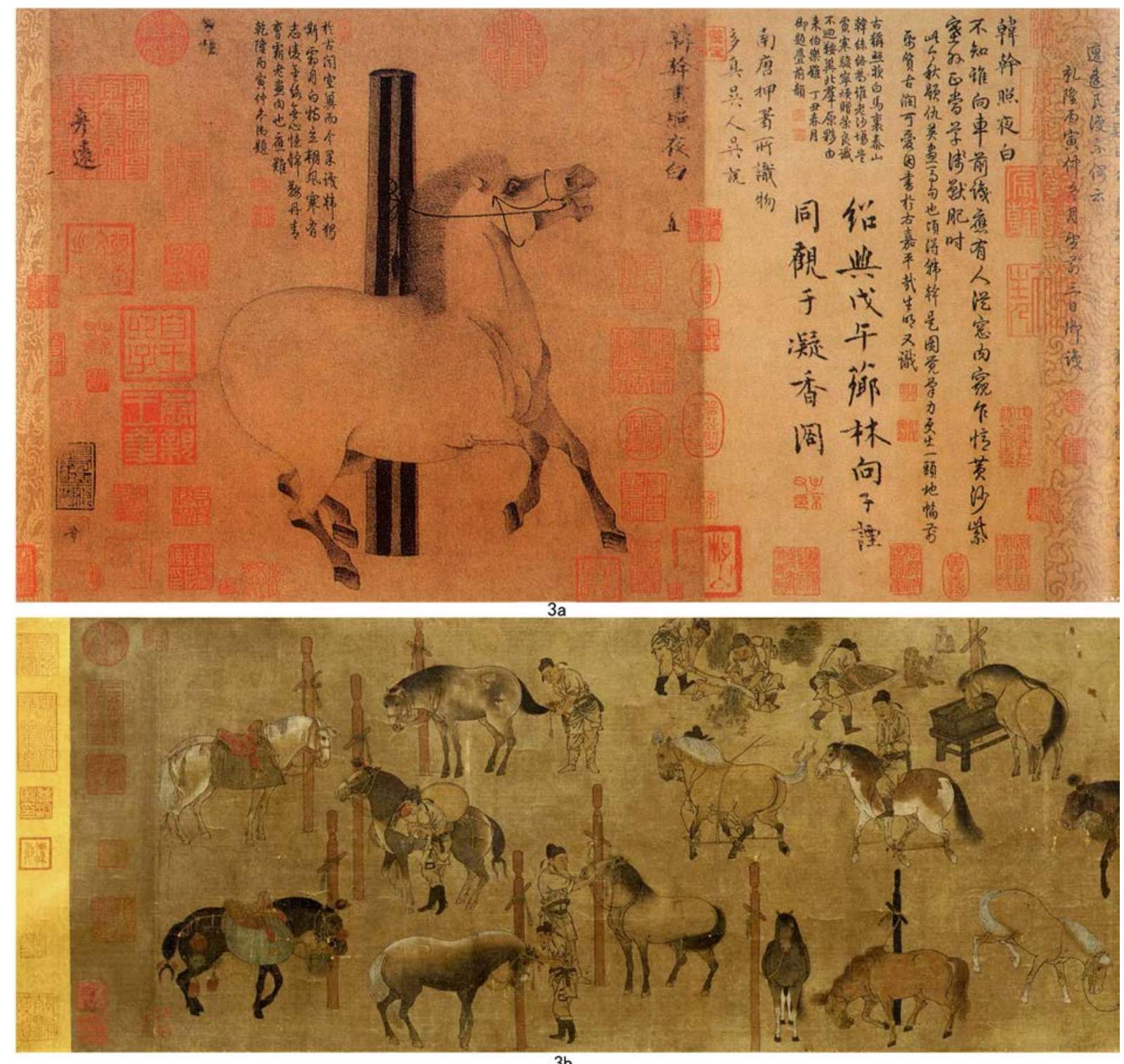

Figure 3. Paintings from the Tang Dynasty; a) Map of Zhao Yebai, Gan Han 706-783 CE; b) Map of Hundred Horses, Yan Wei (approx. $800 \mathrm{CE}$ ).

\section{Classification and symbolism of the horse hitching stone posts}

\subsection{Frequency of patterns}

The horse hitch posts are classified based on the patterns used to adorn the head of the posts. These patterns include lions, Huren on a lion, monkeys, fortune symbols, anthropomorphic figures and rare animals. The character "Huren" was used as a generic term for foreigners in northern or southern China.

Wang \& Dang (1985) roughly evaluated the frequency of different motifs after investigating approximately 3000 stone posts (Table 1). However, some patterns were ignored.

In order to understand the specific proportions of more patterns, we counted the posts in Chengcheng county museum (Shaanxi province); this can then be extrapolated to reflect the proportions of different patterns in the wider region. This distribution is described in Table 2. It is clear that the data in Table 2 is consistent with Table 1. 


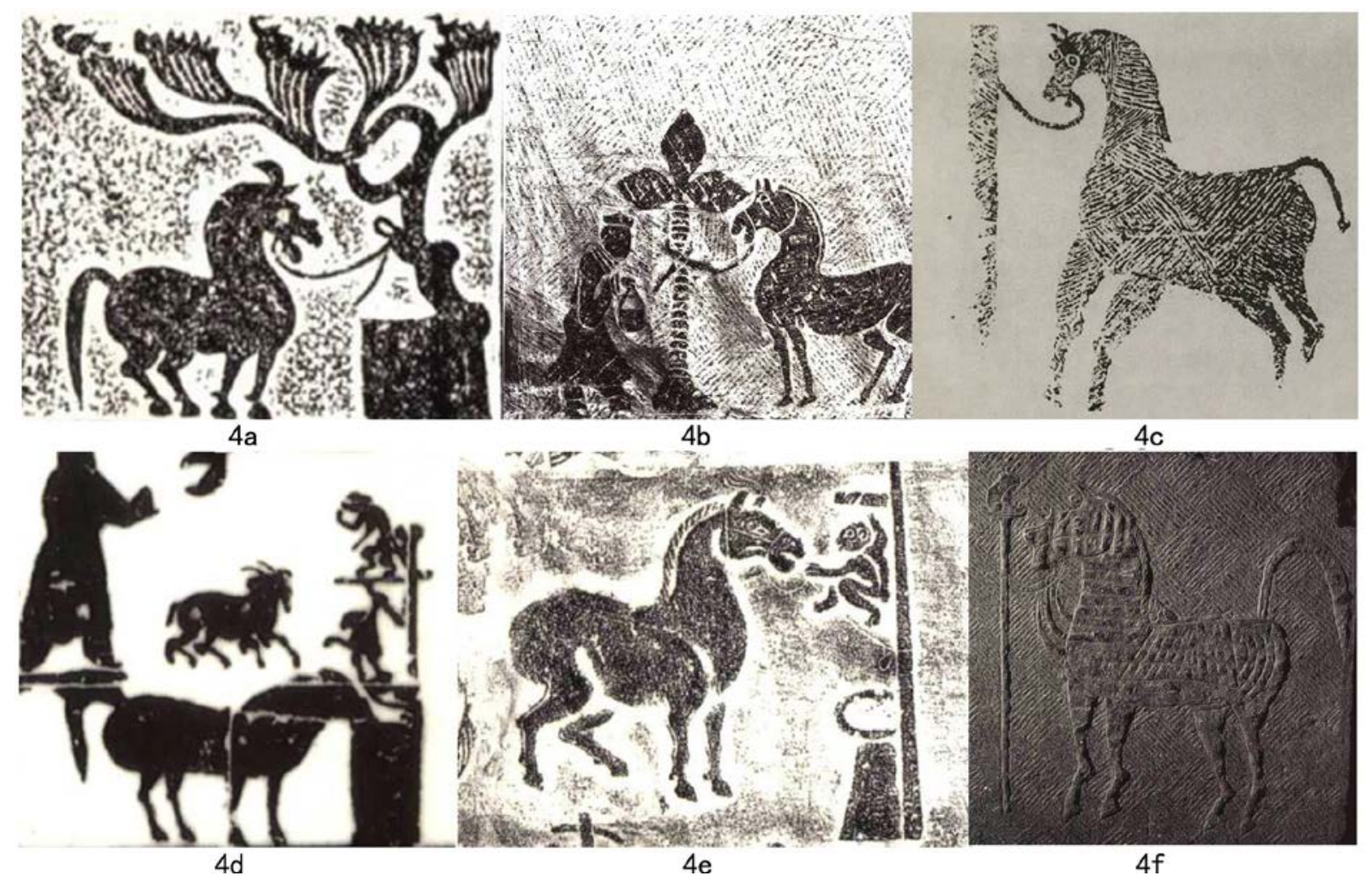

Figure 4. Trees and wood posts: a) Rubbing of Han tomb stone, Suide Han tomb, Shaanxi province (Editorial Committee of the complete works of Chinese portrait stone 2000); b) Rubbing of tomb stone, Xingjing Han stone coffin, Sichuan province (Editorial Committee of the complete works of Chinese portrait stone 2000); c) Rubbing of tomb stone, Hongmiaoziya Han stone coffin, Sichuan province (Gao 2011); d) Rubbing of tomb brick, Mixian Dahuting Han tomb, Henan (Editorial Committee of the complete works of Chinese portrait stone 2000); e) Rubbing of tomb brick, Zengjiabao Han tomb, Sichuan province (Chen 1981); f) Rubbing of Xinjin NO.3 stone coffin, Sichuan province (Editorial Committee of the complete works of Chinese portrait stone 2000).

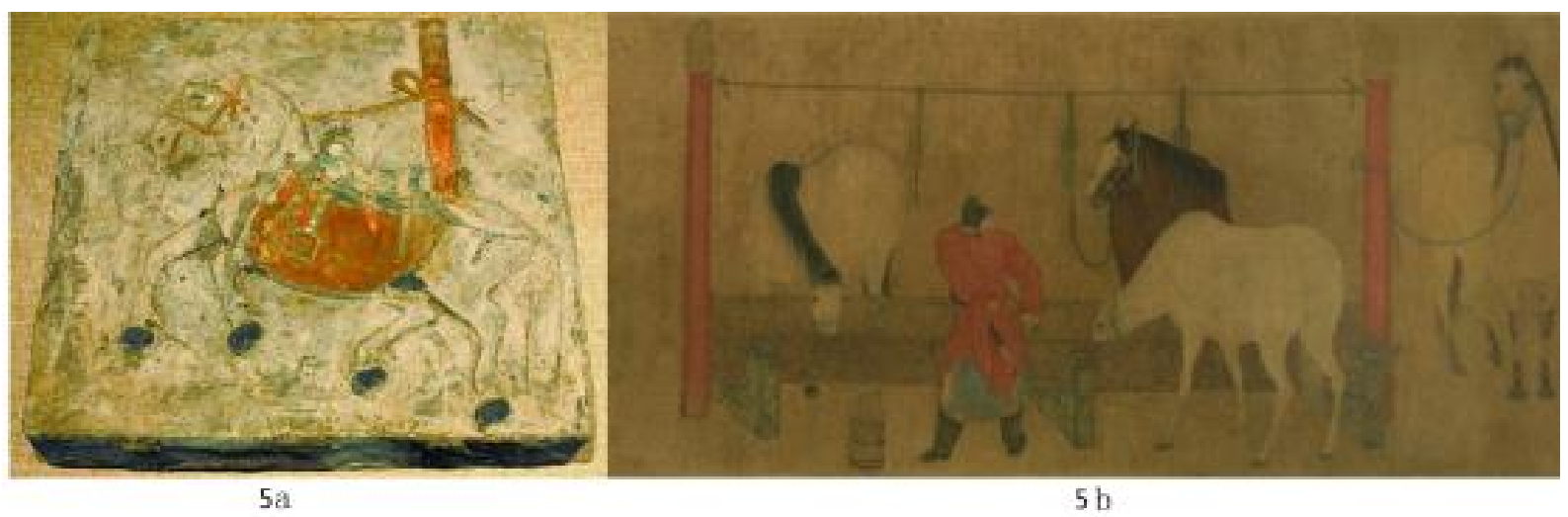

Figure 5. Paintings: a) Tomb brick, Northern Song Dynasty; b) Map of Nine Horses, Renfa Ren, Yuan Dynasty.

\subsection{Patterns}

Each pattern can be divided into several sub-types. Monkeys were depicted as a single animal (Figure 6a), or as a mother and a baby (Figure 6b). Fortune symbols included the orb (Figure 6c), peach (Figure 6d), bud or lotus (Figure 6e), or bat and coin (Figure 6f). Anthropomorphic figures included a goddess of Taoism (Figure 6g), Avaloktesvara with a child (Figure 6h) and a maid (Figure 6i). Avaloktesvara is a Goddess of Mercy, who embodies the compassion of all Buddha. Falcons (Figure 6j, k), elephants (Figure 6l) and horses are all considered rare animals carved on to the stone posts. 
Table 1. Proportion of different patterns in Shaanxi province done by Wang \& Dang (1985)

\begin{tabular}{lll}
\hline Pattern & Percent (\%) & Sub-pattern Percent (\%) \\
\hline Lion & 70 & $\sim$ \\
Monkey & 10 & $\sim$ \\
& & Huren on an animal 90\% \\
Human and animals & 20 & $\begin{array}{l}\text { Anthropomorphic figures, Rare animals } \\
10 \%\end{array}$ \\
\hline
\end{tabular}

Table 2. Proportion of different patterns in Chengcheng county museum

\begin{tabular}{lll}
\hline Pattern & Total number & Percent (\%) \\
\hline Lion & 454 & 63.0 \\
Huren on a lion & 202 & 28.0 \\
Monkey & 43 & 6.0 \\
Anthropomorphic & 6 & 0.8 \\
figures & & \\
Rare animals & 6 & 0.8 \\
Fortune symbols & 10 & 1.4 \\
Total number & 721 & 100.0 \\
\hline
\end{tabular}

\subsubsection{Monkeys}

Monkeys in Chinese culture were directly linked to horse breeding. In ancient times, people believed that monkeys could keep horses healthy and prevent disease.

An (1998, see Figure 7a) and Fu (2002, see Figure 7b) found that as early as the Warring States period (475-221 BCE), monkey and horse breeding were carved together on eave tiles as a fixed combination. $\mathrm{Xu}$ (2017) also noted a lot of images of monkeys in stables or around horses on Han carved tomb stones (Figure 7c, d), like those found in the Han tombs (see Figures 4d-f).

Eiichiro (1948) suggests that the relationship of monkeys and horses spread from India to northern China via Tibet; Wang (2014) studies that Indians believed monkeys could ward off equine plagues. Wang (1998) added that the connection may originate from Erdos (inner Mongolia) based on a bronze decorative piece, depicting a miniature monkey riding on a horse found in the Erdos steppe, dated to the Warring States (circa 800-200 BCE). The connection between monkeys and horse breeding was theorized in the Northern Wei Dynasty. In the book Qimin Yaoshu (Sixie Jia, written in 533-544 CE), the earliest and most complete agricultural encyclopaedia found in China, and it states that tying a monkey in a stable helps ward off diseases (常系猕猴于马坊, 令马不畏避恶, 恶息百病也). In addition, $A$ compendium of Materia Medica (Shizhen Li 1552-1578 CE) states: a female monkey in stable wards off equine plague (马厩畜母猴避马瘟疫).

Later in the Tang (618-907 CE) and Song (960-1279 CE) dynasties, horse breeding and monkeys were still tightly connected. The connection was solidified when monkeys were carved on the top of wooden horse hitching posts (Figure 5b), no later than the Yuan dynasty (1271-1368 CE).

The most popular and wide spread description connecting monkeys to horse breeding is the novel - Journey to the West (Cheng'en Wu 1500-1583), marked as one of the top four Chinese classic novels. The book tells the story of a monkey and his team's adventure. In the story, the Monkey King has a position as a horse keeper, called the protector of horses (Jenner 1982) or Bi-ma-we ( Waley 1961); in Chinese folklore, the monkey could ward off sickness 
from horses. This title is a pun on the words pi (to avoid, to keep off), ma (horse) and wen (pestilence, plague). Alternatively, the monkey was considered a supervisor in the imperial stables (Waley \& Waley 1987).

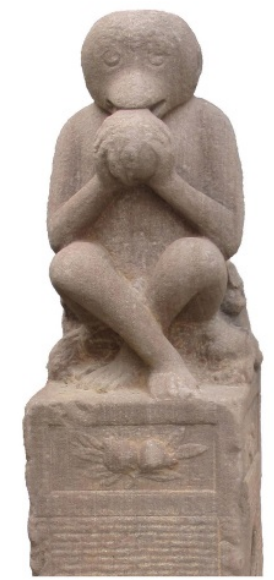

$6 a$

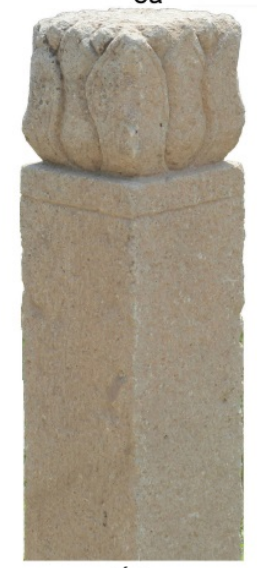

$6 e$

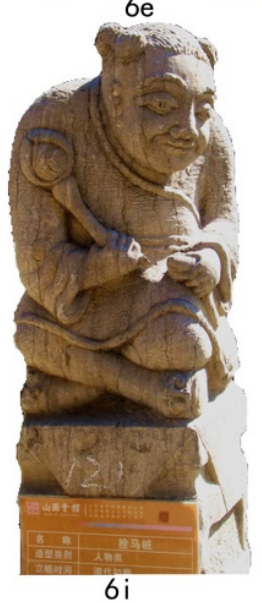

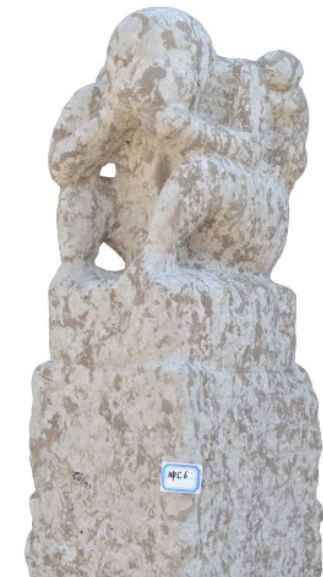

$6 b$

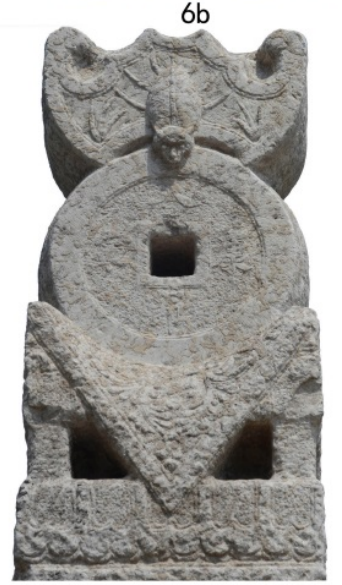

$6 f$

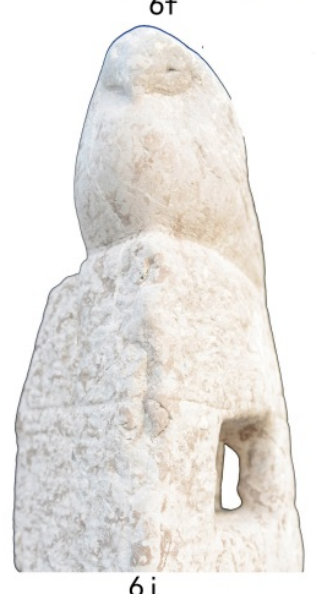

$6 j$
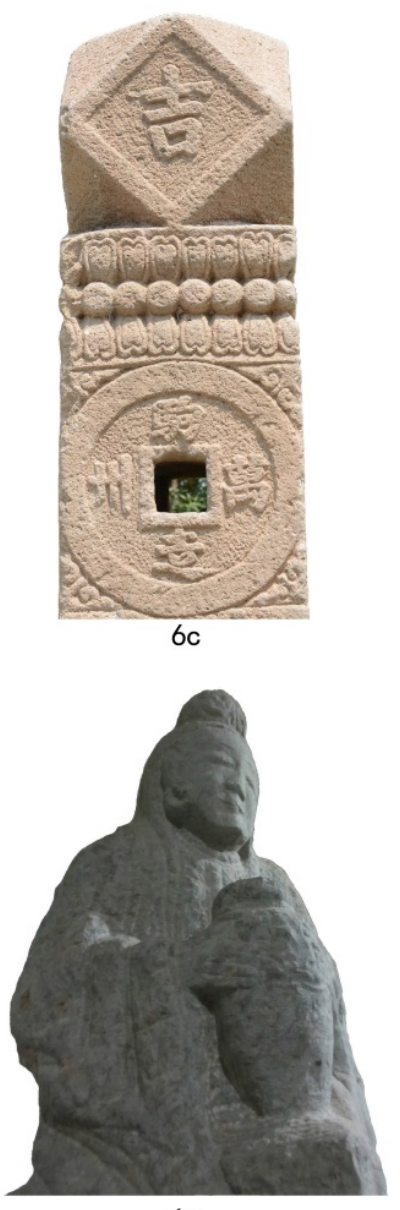

$6 g$

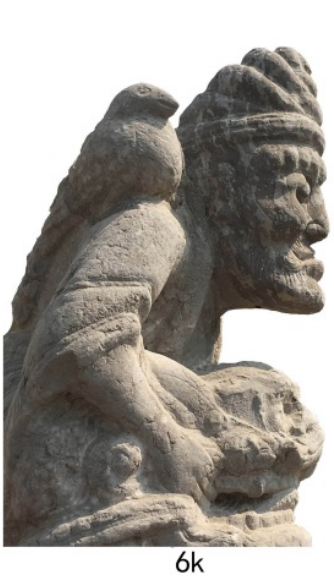

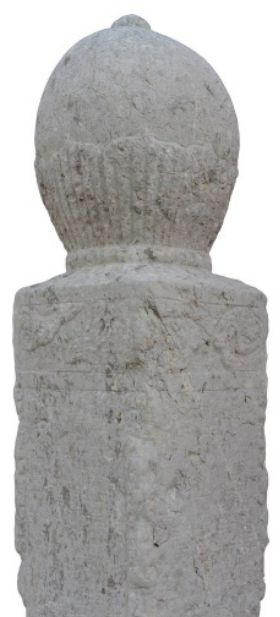

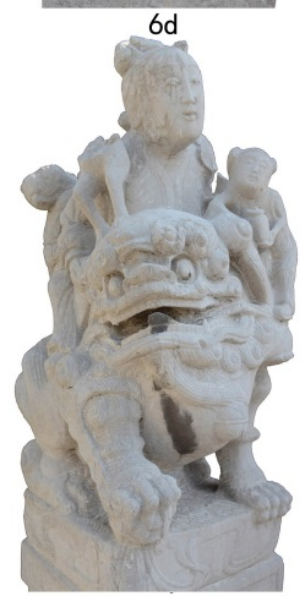

$6 \mathrm{~h}$

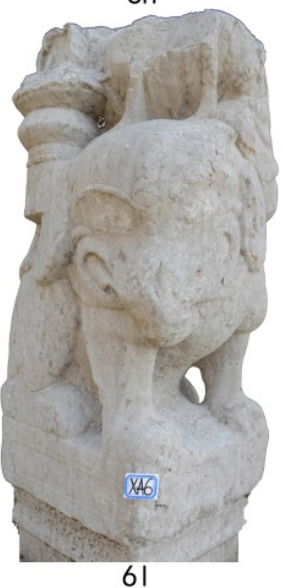

Figure 6. Different patterns of posts: a) Monkey, Xianyang Museum; b) Mother and baby monkey, Chengcheng county museum; c) Fortune symbol - Orb, Fengguosi temple, Liaoning province; d) Fortune symbol - peach, Chengcheng county museum; e) Fortune symbol - bud or lotus, Chengcheng county museum; f) Fortune symbol - bat and coin, Fengguosi temple, Liaoning province; g) Goddess of Taoism, Guanzhong folk art museum; h) Avaloktesvara with a child, Chengcheng county museum; i) Maid, Taiyuan Confucious' temple; j) Falcon, Chengcheng county museum; k) Falcon on Huren's shoulder, Chengcheng county museum; l) Elephant, Chengcheng county museum. 

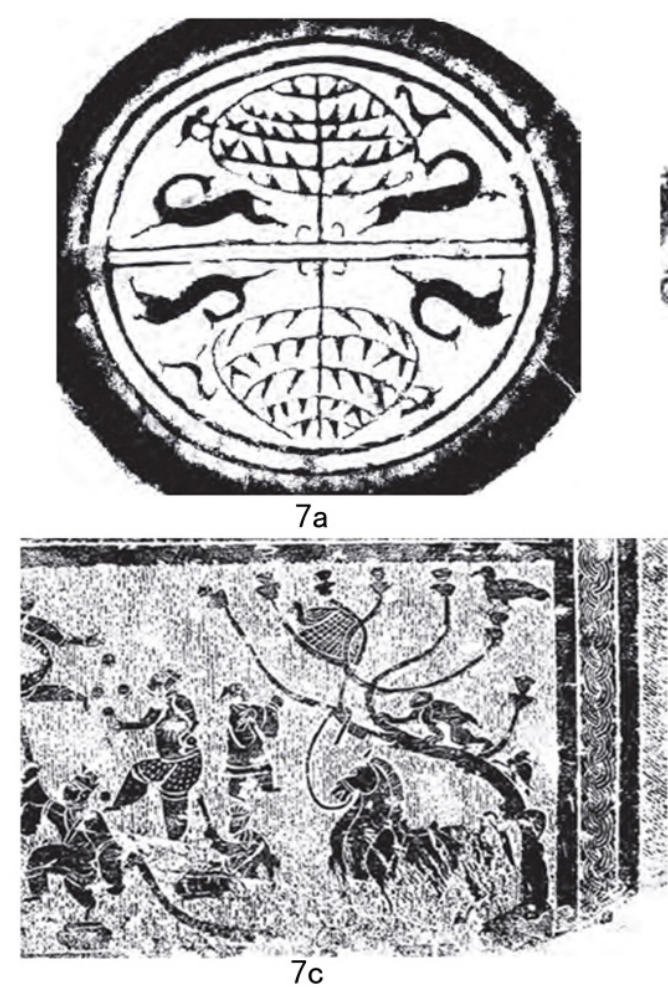
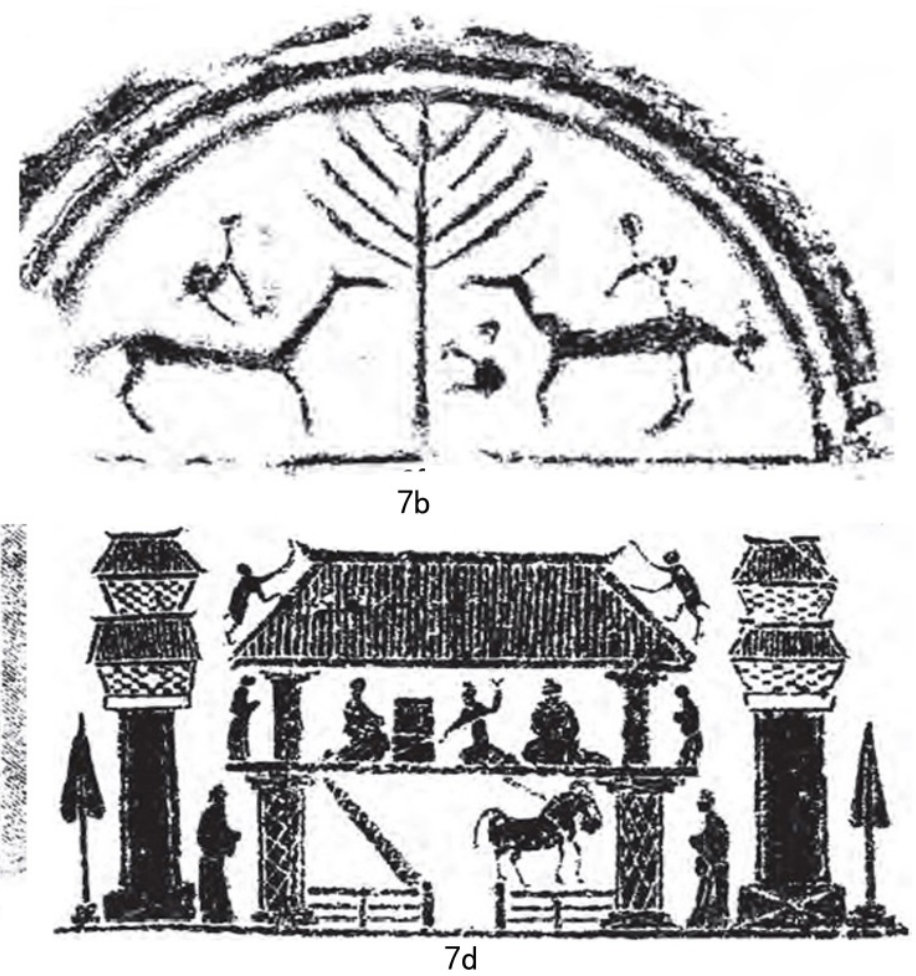

Figure 7. Monkeys and horses in archives: a) Rubbing of eaves tile shows connection of horse and monkey (An 1998); b) Rubbing of eaves tile shows connection of horse and monkey (Fu 2002); c) Han carving, depicting horse breeding and monkey (Xu 2017); d) Han carving, depicting horse breeding and monkey (Xu 2017).
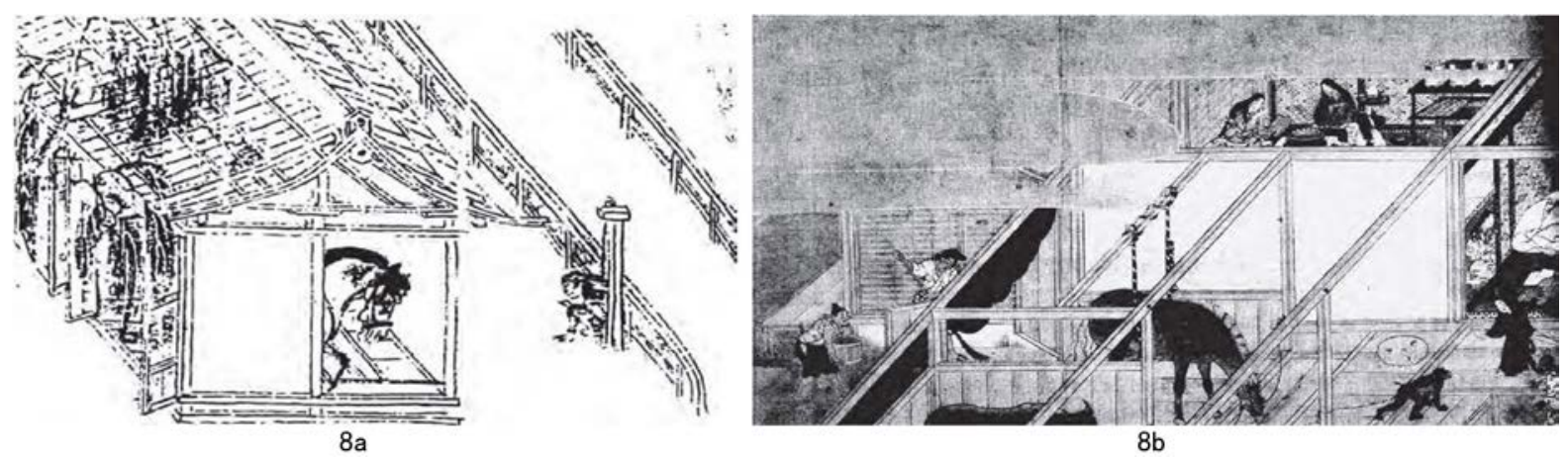

Figure 8. Horse and monkey in Japanese paintings: a) Painting of Ippe, Japan (Chikash 1996); b) Painting of Shishansi (Komatsu 1978).

Furthermore, Chikash (1996) believes that influenced by Han and Tang culture, the horse and monkey fixed combination was also found in famous Japanese paintings dated to the Heian period (794-1192 CE; Figure 8a) and the Kamakura period (1185-1333 CE; Figure 8b).

Additional connections can be noted. In Chinese, the pronunciation of "monkey" is "hou", similar to the nobility rank of a "marquis". Thus, monkeys were used to express one's wish to be promoted to a higher position and rank. A horse, however, is a symbol of battle achievement. The two symbols combined mark the desire to obtain nobility rank because of brilliant battle achievements (Figure 6a). Based on this, the symbol of the mother and baby monkey reflects conferring a rank of nobility generation by generation (Figure 6b).

\subsubsection{Lions}

Lions are not native to China. Lions arrived in to China from Kashmir in $87 \mathrm{CE}$ as a tribute of Parthia (Gu Ban, 32-92 CE). Their images were carved as tomb stones in the royal 
mausoleum garden initially. Later, with the spread of Buddhism, lions became guarding spirits. Lions were used to protect living people, and stone lions were placed in front of temples, and applied on the handrail of bridges for guarding and decoration. Usually lions guarded the house, drove out evil spirits and bestowed blessings. Furthermore, mother and baby lions were traditional auspicious patterns, expressing the wish that the next generation be promoted to senior officials (Figure 9a, b).

In particular, Cheng (1998) found that stone lions were placed in the front of Fang, a residential district, in the Tang Dynasty. The book Rules of Architecture (1103 CE) regulates that only royal and common lords were allowed to use lions while building tombs. Later in the Yuan Dynasty, stone lions transitioned from a sign of the court to a symbol of the common folk. The book Qing Ministry of Construction Regulation (1734 CE) related the hair strand number of a lion to the rank of officers; ordinary people were forbidden from using lions as a symbol.
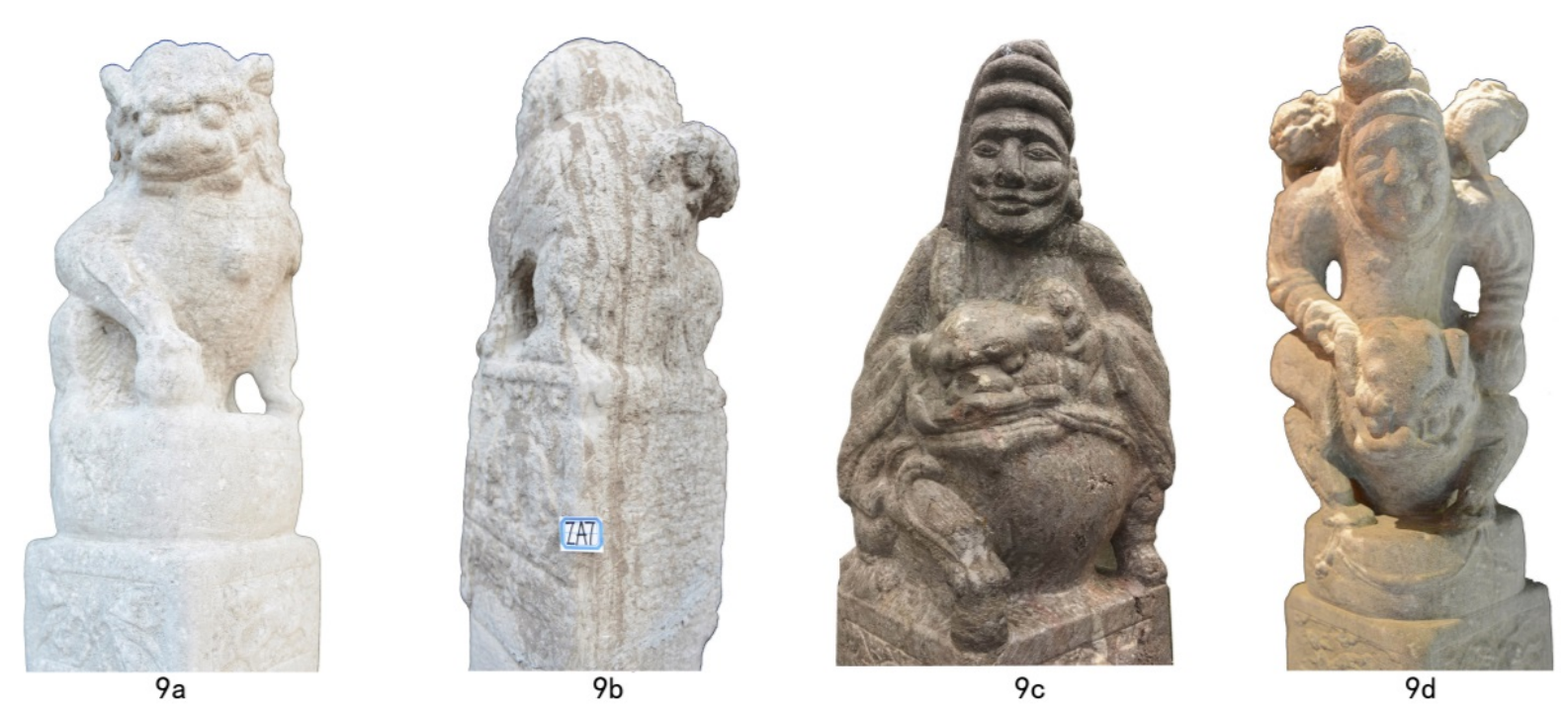

Figure 9. Lions and Huren on lions: a) Lion, Chengcheng county museum; b) Mother and baby lions (backside), Chengcheng county museum c) Huren on a lion, Chengcheng county museum; d) Huren on a lion with baby lions on his shoulder, Chengcheng county museum.

According to the images found from well dated tomb stones and famous maps, lions carved on the tops of stone posts postdate carved monkeys. Statistics shows that lions were the most common stone post adornment (Table 2, 63\%). This occurred because lions bore the heaviest symbolic intent, used not only as a good luck and protective symbol but also as a status symbol. For a long period of time, only nobles, temples and mausoleums were allowed to use stone lions in front of houses. Officials with a position higher than the seventh rank (out of nine ranks) were allowed to use stone lions.

However, unlike stone lions, hitching posts with carved lions were not apparently restricted by laws. We find many lions on hitching posts with thirteen hair strings; this was normally just used by the royal family, and utilization by others would result in the extermination of their entire family. Based on this, we must conclude that this restricted use of lions did not apply to hitching posts. This then explains why stone hitching posts decorated with lions were found in rural areas.

\subsubsection{Huren on lions}

Huren were northern or southern barbarians in ancient China. Lin (2004) explained that Emperor Qianlong conquered Huren tribes, after which the Huren came to Beijing to pay 
tribute. In the book of Emperor Ching Gong, a tribute map (1751 CE) was published; this depicted plenty of figures of Huren and the power of the great emperor. Following this, the image of the Huren was popularized. (Figure 9c, d).

On hitching posts, Huren on lions were sometimes depicted. The combination was used to flatter the emperor, flaunt the owner's wealth, frighten evil spirits and drive away bad luck.

\subsubsection{Fortune symbols}

Fortune symbols refer to several different things: orbs (Figure 6c), peaches (Figure 6d), buds (Figure 6e), bat and coins (Figure 6f), all of which had auspicious meanings derived from a mixture of religions and customs. Orbs and buds (lotus) were lucky symbols of Buddhism, and coins and peaches meant riches and longevity.

\subsubsection{Anthropomorphic figures}

Figures of humans, which differ from Huren, included a single female or a group of figures. The figures were interpreted as a goddess from Taoism (Figure 6g), Avaloktesvara with a child (Figure 6h) or a maid (Figure 6i); the variations were distinguished by the costume, expression and the figure's actions. The goddess and Avaloktesvara were symbols of blessing, and the maid was a symbol of wealth and status.

\subsubsection{Rare animals}

Falcons (Figure 6j, k), elephants (Figure 6l) and, in one example a horse, were found infrequently on the top of posts. Gyrfalcon, an important falcon, was the highest totem of Manchu. During the Qing Dynasty, the falcon was a symbol of great wealth. The falcon alone was found on only one post, but 14 posts bore falcons combined with other figurines. Elephant was a traditional auspicious pattern, meaning peace and ceremony or fresh and joyful. The meaning of the horse on top of a hitching post remains unclear.

\section{Function analysis}

\subsection{Tradition functions}

The traditional functions of horse hitching stone posts were both practical and decorative. The decorative function refers to the symbolisms of the different patterns.

According to the different patterns of carved stone hitching posts, the practical and decorative functions can be summarized as follow: hitching animals, warding off the plague of horses, exorcising evil spirits, flaunting, and blessing. It is obvious that all the posts were used for hitching horses, so the differences in the symbolic function are compared.

From Table 3, we can better understand why lions and Huren on lions comprise the largest fraction of all patterns; the two patterns had more symbolic value than the others.

The stone posts were primarily used in the rural area of northern China. Always a pair of posts was found in front of each house, as the posts' practical function was tied to residential life. None were found in large cities, let alone the capital - Beijing.

It is self-evident that the highly stylized posts were not used by peasants who had no livestock and thus did not need hitching posts. At the same time, it is unlikely that the decorative hitching posts were used by high officials, as these were rare in rural areas. Furthermore, it can be expected that high officials would have generally paid more attention to legality, and would have therefore not used the lion motif anyway. As such, we must conclude that the owners of the posts were rich farmers with horses or cows, but not belonging to nobility. The rich farmers needed to hitch animals in front of the house, and they 
preferred to use the stone posts to show their wealth and status to neighbours as well as gain the associated blessing.

Table3. Symbolic functional comparison of different patterns

\begin{tabular}{lllll}
\hline $\begin{array}{l}\text { Functions/ } \\
\text { Pattern }\end{array}$ & $\begin{array}{l}\text { Warding off } \\
\text { horse plague }\end{array}$ & $\begin{array}{l}\text { Exorcising evil } \\
\text { spirits }\end{array}$ & Flaunting & Blessing \\
\hline Lion & & $\times$ & $\times$ & $\times$ \\
Huren on a lion & & $\times$ & $\times$ & $\times$ \\
Monkey & $\times$ & & $\times$ \\
Fortune symbols & & & $\times$ \\
Anthropomorphic & & & $\times$ \\
Figures & & $\times$ & $\times$ \\
Rare animals & & & \\
\hline
\end{tabular}

\subsection{New functions}

In recent years, stone posts were traded and exchanged on a large-scale. They were collected by colleges, museums, urban parks and individuals. This marks a change in stone hitching post location concentration and function.

Hundreds of stone posts are now aggregated together. Museums arranged posts in a matrix for exhibition. Parks and colleges use posts in the landscape to create a classical environment. Governments made stone posts part of the municipal facilities. In these cases, posts were arranged according to height, regardless of their patterns (Figure 10a, b).

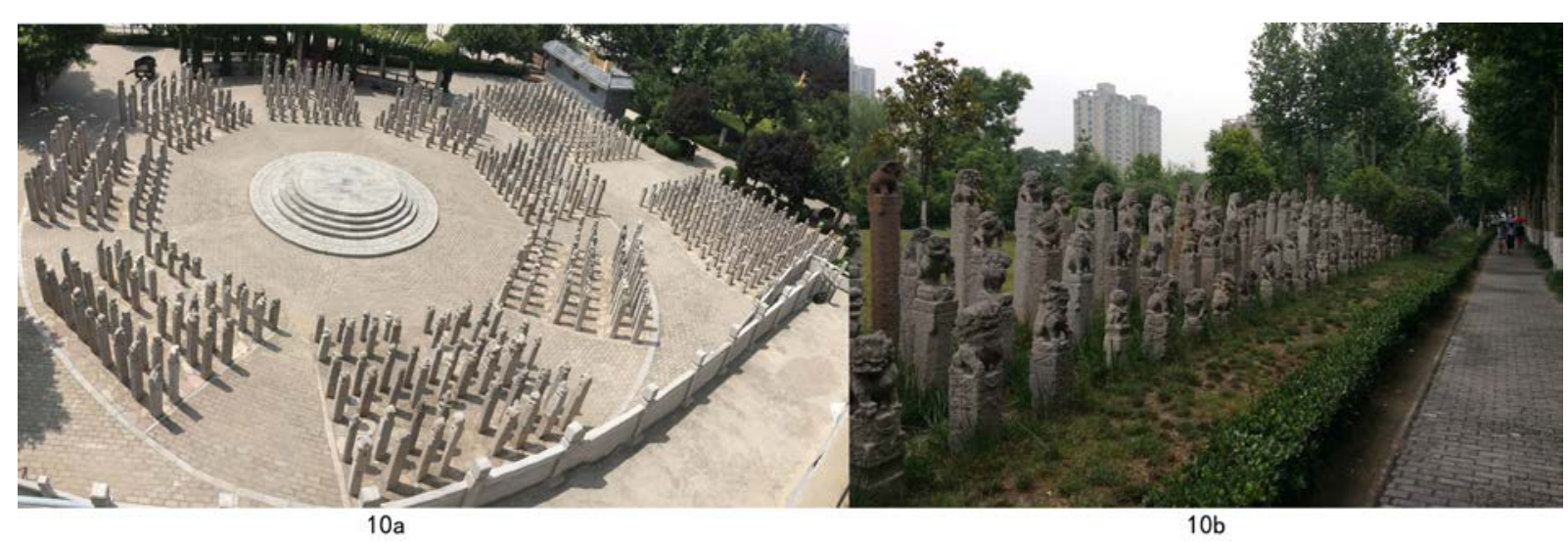

Figure 10. Recent arrangements (photos by Ke Bai): a) Exhibition in matrix of Eight-Diagram position, Chengcheng county museum; b) Landscape in campus of Xi’an Fine Art Academy.

The word horse hitching post is also now used to describe an accessory auricle - a physiological phenomenon around ears (Figure 11a). In Chinese physiognomy, a "horse hitching post ear" means one will have good fortune in their life, which is an extension from the original meaning of horse hitching stone posts.

Golden Shuanmazhuang (horse hitching stone post) is an award given at a college student image art festival held by the Xi'an Fine Art Academy, which was awarded six times as of 2017 (Figure 11b). This indicates that stone posts have become a representation of ancient culture and art.

In the cases above, we find the practical function of stone ignored. People gave stone posts a new abstract concept: historical artwork, lucky symbols and good taste of art. 

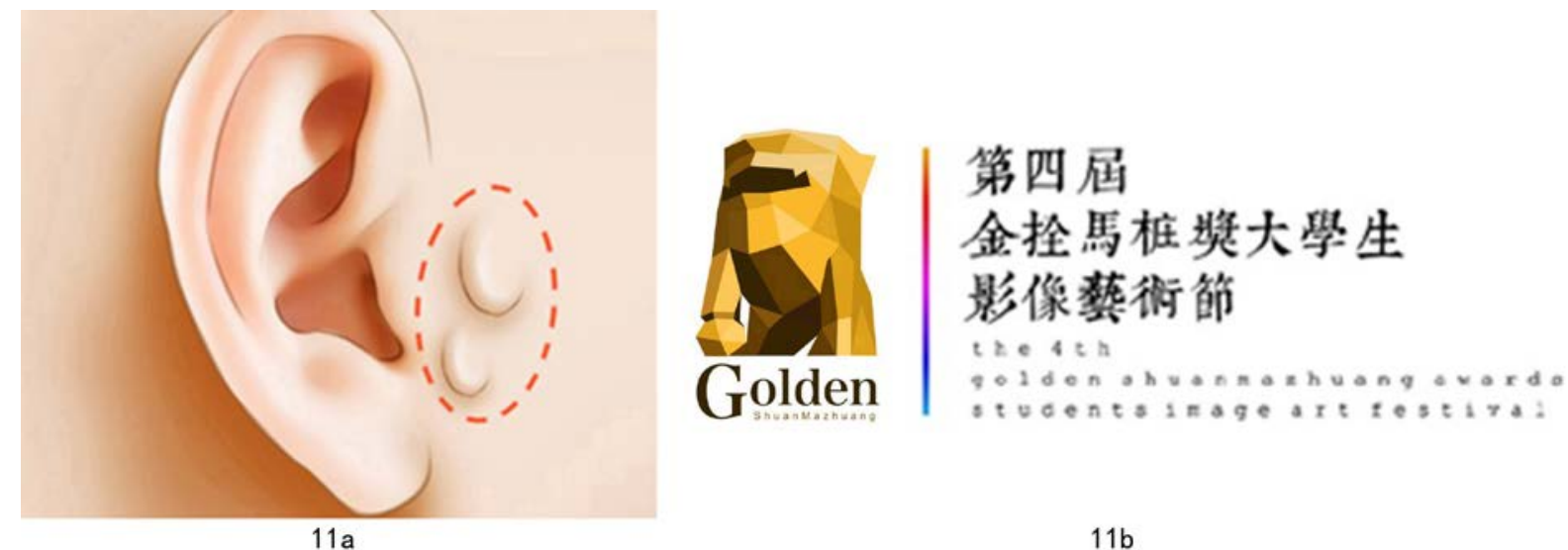

Figure 11. Horse hitching posts in modern time: a) ear-accessory auricle; URL: www.zylmk.com/ebzx/fuerqiechu (Retrieved on 17.03.2019), b) Logo of Golden Shuanmazhuang Image Art Festival. Photo from internet. URL: http://gou.hsw.cn/system/2015/0706/2963.shtml (Retrieved on 17.03.2019).

\section{Conclusion}

The carved horse hitching posts underwent a long evolutionary process: In the Han Dynasty (25-200 CE), horse hitching posts were found depicted on tomb stone as a tree or wood with a tied monkey, with most of them undecorated. The style did not change for a thousand years, until the Yuan Dynasty (1271-1368 CE). Then, the wood posts were painted red, with a carved monkey on the top (see Figure 5b). Finally, the stone horse hitching posts developed sometimes during the 1800-1900s to the collection we can see today.

The patterns became more varied overtime; concomitant to the mixing of customs, religion and policy. Thus, also the symbolic meaning became more complex.

The function of the hitching posts also changed in modern times. The stone posts were used by single families in rural areas for practical and symbolic purposes. They were used for tying animals, exorcising evil spirits, flaunting and obtaining blessing. Overtime, the stone hitching posts were sold and transported in the market to cities, and the original function was forgotten. The posts were used by organizations in cities, such as museums, campuses, institutes and parks. The posts were exhibited as landscape pieces or as decoration in classical gardens. With this, people extended the function of the stone posts as historical art works, lucky symbols and aesthetic pieces of art.

\section{References}

An, L. 1998, 齐国瓦当艺术. 人民美术出版社, Beijing, 129 p. (in Chinese) (“Art of eaves tiles of Warring States Qi”)

Ban, G. 105 CE, 汉书. 中华书局, Beijing, 4273 p. (in Chinese) (“Book of Han”)

Chen, X. 1981, 四川成都曾家包东汉画像砖石墓. 文物, 27(10): 25-32, 100. (in Chinese)

("Eastern Han Carving Bricks of Zengjiabao in Chengdu, Sichuan”). CNKI doi:CNKI:SUN:WENW.0.1981-10-005

Cheng, Z. 1998, 元代石狮趣谈. 文史知识, 18(9): 49-51 (in Chinese) (“Studies in Stone Lions in Yuan Dynasty”)

Chikash, K. 1996, 日本马事文化の源流. 芙蓉书房, Tokyo, 291 p. (in Japanese) (“Origin and Development of Japanese Horse Culture”) 
Editorial Committee of the complete works of Chinese portrait stone 2000, 中国画像石全集 -陕西山西汉画像石, 山东美术出版社, Jinan, 259 p. (in Chinese) (“Complete works of Chinese portrait stone- portrait stones in Shaanxi and Shanxi”)

Eiichiro, I. 1942, 河童駒引考, 筑摩书房, Tokyo, 273p. (in Japanese) (“Study of Kappa”)

Fu, J. 2002, 中国瓦当艺术. 上海书店出版社, Shanghai, 964 p. (in Chinese) (“Art of Chinese eaves tile”)

Gao, W. 2011, 中国画像石棺全集. 三晋出版社,Taiyuan, 671 p. (in Chinese) (“The Complete Collection of Chinese Portrait Sarcophagus”)

Hu, W. 2015, 拴马桩, 南方都市报, 28 ${ }^{\text {th }}$ Dec, GB07. (in Chinese) (“Horse hitching stone”)

Jia, S. 533-544 CE, 齐民要术. (in Chinese) (“QiminYaoshu”)

Komatsu, S. 1978, 石山寺绘卷, 日本の絵巻. 中央公论社, Tokyo, 147p. (in Japanese) (“Japanese painting collection”)

Li, S. 1552-1578, 本草纲目. (in Chinese) (“Compendium of Materia Medica”)

Lin, T. 2004, 从职贡图到八蛮进宝和回回进宝-陕西关中拴马桩人驭狮雕像试读. 美术观 察, 10(1): 98-100. (in Chinese) ("From Ching Gong tribute map to tribute of Huren and Muslim-try to read the statue of Huren on a lion in the Guanzhong area in Shaanxi"). doi:10.3969/j.issn.1006-8899.2004.01.030

Sun, J. 1991, 汉代物质文化资料图说, 文物出版社, Beijing, 644p, (in Chinese) ("Illustration Explanations of the Material Culture of the Han Dynasty")

Wang, N. \& Dang, R. 1985, 渭北拴马石艺术考察记, 美术研究, 11(3): 37-40; 49-62. (in Chinese) ("Study Record on Horse Hitching Stones in Weibei Area”)

Wang, X. 1998, 鄂尔多斯猴子骑马青铜饰与《西游记》中张马温的由来, The fortieth anniversary Symposium of Shaanxi archaeology Institute, p. 431-434, 陕西人民美术出 版社, Xi'an, (in Chinese) (“An Erdos Monkey-riding Bronze Decoration and the Origin of Bi Ma-we in Journey to the west”)

Wang, Z. 2014, “猿骑”考-借助汉代画像资料的探索, 文物, 60(5): 56-62+1. (in Chinese) (“On the 'Yuanji'-the Research Referring to the Pictorial Materials of the Han Dynasty”)

Wu, C’e. 1984, Journey to the West. $2^{\text {nd }}$ edition, translated by W.J.F. Jenner, Foreign Language Press, Beijing, $630 \mathrm{p}$.

Wu, C’e. 1994, 西游记. Hainan Publishing House, Hainan, 372 p. (in Chinese) (“Journey to the West")

Wu C’e. 1961, Monkey, translated by Waley, A., Penguin Books, London, 351 p.

Wu C'e, 1987, Adventures of the Monkey God, translated by Waley, A. \& Waley, A., Graham Brash, Singapore, 233 p.

Wu, X. 2002, 话说栓马桩, 收藏界, 1(1): 15-17. (in Chinese) (“Talking about horse hitching stones”). CNKI DOI: CNKI:SUN:SCJE.0.2002-01-003 
Xu, C. 2017, 貆马温、马上封侯与射爵一汉画像中的细节内涵, 中国国家博物馆馆刊, 171(10): 69-89. (in Chinese) ("Details in Han Carvings: The Horse Keeper, Monkey on the Horse and Bird Shooting”)

Yan, X. 1991, 渭北拴马桩初探, 文博, 36(3): p.35-39. (in Chinese) (“Preliminary study in horse hitching stone in Weibei area”). CNKI DOI: CNKI:SUN:WEBO.0.1991-03-007

Ye, H., Meng, B. 2017, 关中民俗艺术博物院拴马桩的艺术形象与价值, 长春师范大学学 报, 36(8): 169-173. (in Chinese) (“The Artistic Image and Value of the Horse Hitching Stones in Guanzhong Folk Art Museum”). CNKI DOI: CNKI:SUN:CCSS.0.2017-08045

Zhang, Y. 1992, 渭北拴马桩-美术史上一个不可忽视的文化现象, 西北美术, 11(3): 34-37. (in Chinese) ("Horse hitching stone in Weibei area: An Important Cultural Phenomenon in Art History”). CNKI DOI: CNKI:SUN:XBMS.0.1992-03-007

Zhou, D., Wang, J., Yao, Z. 2011, 陕西关中民间桩柱石雕的生成时代新论, 长沙理工大学 学报(社会科学版), 26(6):117-121. (in Chinese) (“The New Theory of Folk Carved Horse Hitching Stone in Guanzhong Area in Shaanxi”). doi:10.3969/j.issn.1672934X.2011.06.022

Zhu, X. 2008, 拴马桩形成与发展的历史文化内涵研究[M], Xi'an: Shaanxi Normal University. 47p, (in Chinese) ("Research on the Historical and Cultural Connotation of the Formation and Development of the Beast Pillar") 